\title{
Metode Interference Cancellation yang Efisien pada Jaringan Nirkabel Area Tubuh
}

\author{
Putrissa Damayanti, Wirawan, dan Titiek Suryani \\ Jurusan Teknik Elektro, Fakultas Teknologi Industri, Institut Teknologi Sepuluh Nopember (ITS) \\ Jl. Arief Rahman Hakim, Surabaya 60111 \\ e-mail: putrissa.damayanti12@mhs.ee.its.ac.id,wirawan@ee.its.ac.id, titiks@ee.its.ac.id
}

\begin{abstract}
Abstrak-Jaringan Nirkabel Area Tubuh (Wireless Body Area Network) adalah sensor yang berada pada tubuh manusia yang bisa langsung berkomunikasi kepada perangkat penerima secara nirkabel. Aplikasi yang digunakan dari WBAN ini adalah untuk membantu memudahkan dalam bidang kesehatan untuk pasien agar data pengukuran di tubuh bisa langsung diterima oleh dokter agar segera diperiksa. Pada kanal WBAN sangat rentan terhadap gangguan, yaitu gangguan berupa Intersymbol Interference (ISI) maupun Multiple Access Interference (MAI). Kesalahan dalam pengiriman data pasien akan sangat membahayakan. Diperlukan metode pengurangan gangguan untuk mengatasi masalah tersebut. Successive Interference Cancellation banyak diterapkan untuk mengatasi masalah gangguan yang terjadi pada sistem MIMO. Pada studi ini didapatkan skema yang paling efisien untuk mengurangi eror akibat interferensi pada kanal WBAN yaitu dengan menggunakan sistem komunikasi MIMO Alamouti dan menambahkan equalizer Zero Forcing dan Successive Interference Cancellation menghasilkan nilai BER 0,0001 pada EbNo=14.
\end{abstract}

Kata Kunci- kode Gold, MIMO Alamouti, Successive Interference Cancellation, Wireless Body Area Network, Zero Forcing.

\section{PENDAHULUAN}

$\mathrm{D}^{1}$ ERA sekarang teknologi di berbagai bidang berkembang sangat pesat salah satunya di bidang komunikasi nirkabel. Pertumbuhan yang cepat dari komunikasi nirkabel, sensor, dan sirkuit berdaya rendah menghasilkan perkembangan dari sebuah generaasi baru dari jaringan sensor nirkabel. Jaringan sensor digunakan di produk perkebunan, volume kepadatan pada suatu jalanan, dan pemantauan kesehatan. Perkembangan dari perangkat sensor memungkinkan untuk membangun suatu jaringan sensor nirkabel yang murah, mudah digunakan dan dapat dipakai di tubuh yaitu disebut jaringan nirkabel area tubuh (Wireless Body Area Network/ WBAN). Perkembangan teknologi WBAN dimulai sekitar tahun 1995 dengan mempertimbangkan jaringan wilayah pribadi nirkabel (WPAN) teknologi untuk komunikasi pada, di dekat dan di sekitar tubuh manusia. Kemudian sekitar tahun 2001, aplikasi ini WPAN dinobatkan sebagai jaringan tubuh daerah (BAN) untuk mewakili komunikasi di dalam dan dekat tubuh saja.

Wireless Body Area Network (WBAN) adalah sebuah konsep jaringan baru yang memfasilitasi komunikasi data menggunakan node sensor yang dapat dipakai atau di implant di tubuh manusia. WBAN dapat memonitor sinyal sinyal fisiologis yang vital dengan daya yang rendah. Data yang didapatkan dari sensor sensor tersebutakan dikirim ke node remote melalui jaringan nirkabel lalu data tersebut diteruskan ke layer yang lebih tinggi untuk dapat dianalisis. Alat ini menggunakan energi yang kecil sesuai dengan bentuknya yang kecil, murah dan mudah di implementasi, dan memiliki kecepatan data dengan range Kbps ke Mbps. WBAN terdiri dari beberapa peralatan mobile dan node sensor nirkabel yang saling berkomunikasi yang dapat dipakai atau diimplan di tubuh manusia. Pada komunikasi WBAN penurunan kinerja dapat terjadi sebagai akibat dari Intersymbol Interference (ISI), Multiple Access Interference (MAI), dan Multipath Fading. Ketika ada beberapa perangkat komunikasi nirkabel pada tubuh manusia, Multiple Access Interference biasanya akan muncul. Maka dari itu diperlukan suatu skema Interference Cancellation yang effisien dapat mengurangi efek MAI dan mendapat keuntungan tambahan pada sebuah sistem WBAN dengan meminimalkan terjadinya eror.

\section{TEORI PENUNJANG}

\section{A. Jaringan Nirkabel Area Tubuh}

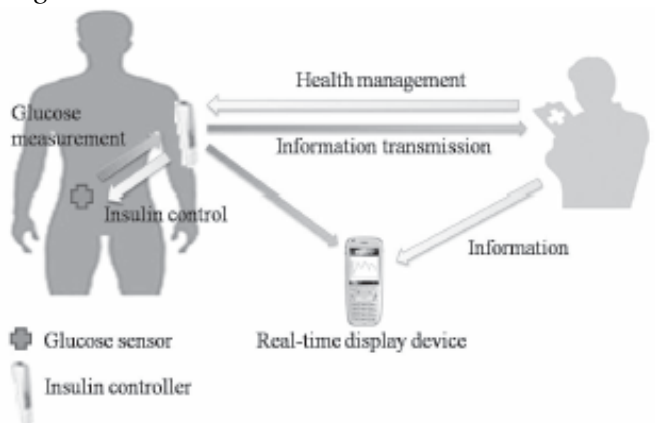

Gambar 1. Sistem U-Health [2]

Sebuah jaringan area tubuh (Body Area Network/ BAN) adalah jaringan yang terdiri dari satu set node heterogen yang bisa merasakan, menggerakan, menghitung, dan berkomunikasi satu sama lain melalui saluran multihop nirkabel. Sebuah BAN dapat mengumpulkan, memproses, dan menyimpan catatan fisiologis seperti sensor aktifitas jantung atau elektrokardiogram (ECG), sensor suhu tubuh, dan tekanan darah pada setiap aktifitas yang dilakukan seperti saat sedang berjalan, berlari, ataupun saat tidur. Selain itu BAN juga dapat merekam lingkungan seperti suhu, kelembaban, dan kehadiran alergen, lalu parameter dari tubuh manusia dan lingkungan sekitarnya. Bahkan BAN bisa melakukan pemberian pengobatan atas dasar data yang dikumpulkan. BAN dapat sangat berguna dalam membantu para profesional medis untuk membuat keputusan tentang pengobatan pasien dengan menyediakan mereka informasi secara terus menerus tentang kondisi pasien[1]. Sistem ini disebut juga dengan ubiquitos healthcare (u-health) yang dapat dilihat pada gambar 1.Jika BAN ini terpasang secara nirkabel, maka dinamakan dengan Jaringan Nirkabel Area Tubuh (Wireless Body Area Network/ WBAN). WBAN adalah sebuah konsep jaringan 
yang telah berkembang dengan tujuan memonitor sinyal fisiologis penting dari sensor berdaya rendah pada tubuh manusia. Data yang dikumpulkan dari sensor akan di kirim ke node lain melalui media nirkabel, dimana data tersebut diteruskan ke layer aplikasi yang lebih tinggi untuk diartikan.

\section{A. Karakteristik Kanal WBAN}

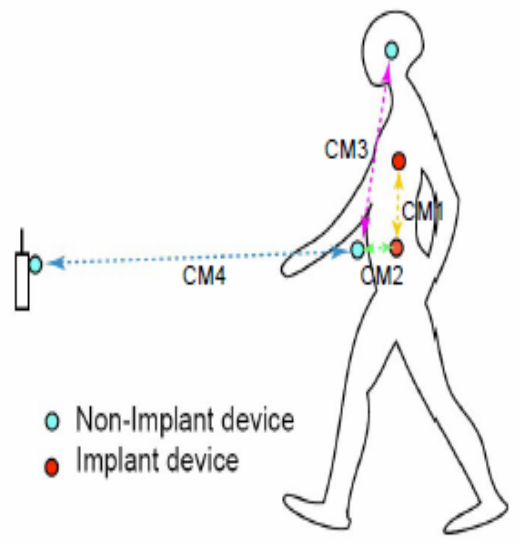

Gambar 2. Jalur Komunikasi WBAN [3]

Terdapat beberapa skenario komunikasi yang dapat diidentifikasi berdasarkan lokasi node sensor. Skenario dikelompokan delam kelas yang dapat diwakili oleh model kanal (Model Channel/CM). Jarak dari perangkat eksternal dianggap maksimal 5 meter. Jalaur komunikasi yang memungkinkan pada WBAN dapat dilihat pada gambar 2 dibawah ini.

WBAN CM4, respon impuls kanal kompleks his sejumlah $i$ perangkat diberikan sebagai berikut [3]:

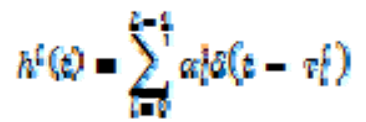

$$
\begin{aligned}
& \|\left.\alpha\right|^{2}=\Omega_{\beta} \operatorname{\omega p}\left(-\frac{\nabla h}{\Gamma^{2}}-F_{h}[1-\delta(D)] \beta\right. \\
& F_{k}=\frac{\Delta k \ln 10}{10}
\end{aligned}
$$

Dimana:

$h^{\mathbf{3}}\left(\mathrm{e}^{2}\right)$ : Respon impuls komplek kanal

L : Jumlah total jalur kedatangan, dan dimodelkan sebagai variabel acak Poisson dengan rata rata $\bar{L}=$ 400

$\alpha \quad$ : Amplitudo dari setiap jalur

$\tau_{\text {l }}$ : Waktu jalur kedatangan, dimodelkan sebagai proses acak Poisson, dengan laju kedatangan 2. $=180,80123 \mathrm{~ns}$

$\Omega_{0} \quad$ : Path loss, dapat diasumsikan pada ruang bebas

I' : Peluruhan eksponensial

$\beta \quad$ : Variabel acak log normal dengan rata rata 0

$\mathbf{F}_{\mathbf{k}} \quad$ : Efek dari faktor-K pada lingkungan non-line-ofsight

$\Delta \mathbf{s} \quad$ : Perbedaan antara besaran dari respon impuls pertama dan rata-rata dari respon impuls
Tabel 1. Parameter kanal WBAN CM 4 untuk arah yang berbeda pada tubuh [3]

\begin{tabular}{cccc}
\hline $\begin{array}{c}\text { Arah di } \\
\text { tubuh } \\
\text { (dalam } \\
\text { derajat) }\end{array}$ & $\begin{array}{c}\text { Faktor } \\
\text { peluruhan } \\
\text { eksponensial: } \boldsymbol{T} \\
\text { (dalam ns) }\end{array}$ & $\begin{array}{c}\text { Faktor }-\mathrm{K}: \\
\mathbf{F}_{\mathbf{k}} \text { pada } \\
\text { NLOS }\end{array}$ & $\begin{array}{c}\text { Varians: } \boldsymbol{\sigma} \\
\text { (dalam } \\
\text { dB) }\end{array}$ \\
\hline 0 & 44,6346 & 5,111 & 7,3 \\
90 & 54,2868 & 4,348 & 7,08 \\
180 & 53,4186 & 3,638 & 7,03 \\
270 & 83,9635 & 3,983 & 7,19 \\
\hline \hline
\end{tabular}

Pada tabel 1 menunjukan nilai dari $\boldsymbol{l}^{\prime}, \mathfrak{F}_{\vec{k}}$, untuk orientasi yang berbeda beda pada tubuh manusia.

\section{B. Kode Gold}

Salah satu metode yang umum digunakan untuk membangkitakan PN code adalah gold codes. Kode Gold disusun dari dua buah M-sequence dengan memperhatikan preferred pair setiap M-sequence. Masing masing output dari M-sequence ditambahkan secara XOR menggunakan pulsa-pulsa clock yang sinkron, dimana kedua M-sequence mempunyai panjang yang sama dengan periode sinyal PN.

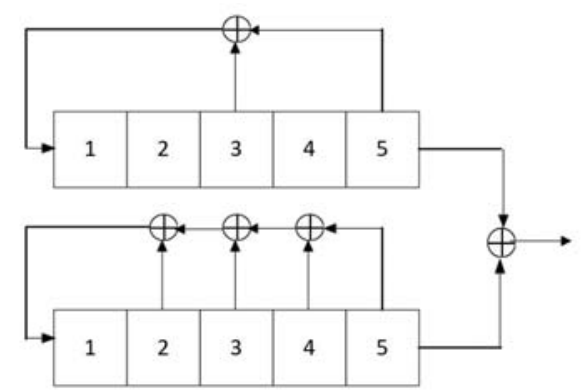

Gambar 3. Diagram blok kode Gold 31 bit [4]

Setiap pembangkitan masing-masing M-sequence pada kode Gold harus memperhatikan preferred pairs. Karena preferred pairs mengatur proses penambahan modulo 2 pada masing-masing shift register. Kode Gold memiliki nilai fungsi korelasi yang sama dengan $\mathrm{M}$-sequence yaitu $\{-1 / \mathrm{N}$, ( $\left(m^{2}\right) / \mathrm{N},\left(\right.$ ( $\left.\left.\left(m^{2}\right)-2\right) / \mathrm{N}\right\}$, dimana:

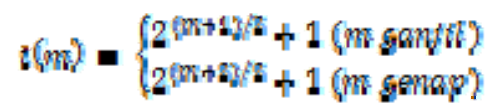

Proses pergeseran dan XOR akan terus dilakukan terus sampai N-1 atau jumlah deretan kode yang dihasilkan memenuhi persamaan berikut ini:

$$
n=2^{n}-1
$$

Dimana $\mathrm{n}=$ jumlah kode yang dihasilkan dari proses pergeseran dan XOR antara himpunan b dan himpunan a, m adalah panjang register. Dari persamaan diatas dan kemudia dijumlahkan dengan dua himpunan pembentuk kode Gold didapatkan satu himpunan besar kode Gold yang dapat digunakan. Persamaan menentukan banyaknya kode Gold yang dibangkitkan adalah:

$$
\theta n=2^{m}-1+2
$$

Dimana $\mathrm{Gn}=$ banyak kode Gold yang dibangkitkan. Angka +2 adalah dua himpunan untuk membangkitkan kode 
Gold. Proses pembangkitan kode Gold dapat dituliskan seperti persamaan berikut ini [5]:

$$
\begin{aligned}
& G(a, b)=\left\{a_{l} b_{l} a \oplus b, a \oplus T b_{l} a \oplus T^{2} b_{l} a \oplus T^{2} b_{l}, a \oplus T^{N-1} b\right\} \\
& \text { C. MIMO Alamouti }
\end{aligned}
$$

\section{MIMO Alamouti}

Sistem komunikasi Multiple Input Multiple Output (MIMO) terdiri dari beberapa antena pemancar dan beberapa antena penerima. MIMO merupakan suatu teknologi yang muncul menggunakan prinsip diversity dengan tujuan meningkatkan data rate dalam range yang lebih besar tanpa membutuhkan bandwidth atau daya transmisi yang besar. Performansi MIMO sendiri dipengaruhi oleh kombinasi jumlah antena pada pengirim dan penerima dan juga metode/algoritma deteksi MIMO-nya [6]. Sistem multiple-input multiple-output (MIMO) adalah sistem yang menggunakan multi antena baik pada transmitter maupun receiver untuk mengatasi kelemahan pada sistem komunikasi wireless konvensional diantaranya adalah large scale fading, small scale fading termasuk dildalamnya multipath fading serta interferensi dari sinyal lain. Rumus model sistem MIMO adalah sebagai berikut [7]:

$$
y=F x+n
$$

Dimana terdapat simbol bervariasi yaitu:

$$
\mathbf{y}=\left[\begin{array}{c}
y_{1} \\
y_{2} \\
\vdots \\
y_{N}
\end{array}\right] \quad \mathbf{x}=\left[\begin{array}{c}
x_{1} \\
x_{2} \\
\vdots \\
x_{M}
\end{array}\right] \quad \mathbf{H}=\left[\begin{array}{cccc}
h_{11} & h_{12} & \cdots & h_{1 M} \\
h_{21} & h_{22} & \cdots & h_{2 M} \\
\vdots & \vdots & \ddots & \vdots \\
h_{N 1} & h_{N 2} & \cdots & h_{N M}
\end{array}\right] \quad \mathbf{n}=\left[\begin{array}{c}
n_{1} \\
n_{2} \\
\vdots \\
n_{M}
\end{array}\right]
$$

Keterangan:

$\mathrm{y}=$ vektor penerima

$\mathrm{x}=$ vektor pengirim

$\mathrm{H}=$ matriks transmisi kanal/saluran

$\mathrm{n}=$ vektor derau (noise)

Alamouti code merupakan teknik transmit diversity sederhana yang mampu meningkatkan kualitas sinyal dengan menggunakan dua antena pemancar atau sembarang jumlah antena. Metode ini mampu meningkatkan performansi BER, data rate atau kapasitas dari sistem komunikasi tanpa kabel dengan tidak membutuhkan bandwidth tambahan. Metode ini efektif dalam aplikasi yang kapasitas sistemnya dibatasi oleh multipath fading.

Proses dari MIMO Alamouti apat dilihat pada gambar 4. Dua sinyal hasil dari MIMO Alamouti yang akan dikirimkan ke decoder adalah sebagai berikut [8]:

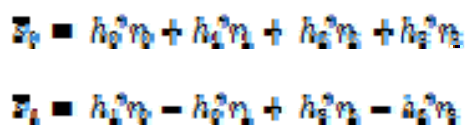

\section{B. Zero Forcing}

Zero Forcing merupakan salah satu jenis ekualiser yang mengacu pada bentuk algoritma pemerataan linier yang digunakan dalam sistem komunikasi dimana berfungsi untuk membalikkan respon frekuensi pada saluran. Equalizer ini penerapannya pada invers (kebalikan) pada kanal ke sinyal yang diterima, untuk mengembalikan sinyal semua sebelum masuk ke dalam kanal. Dinamakan Zero Forcing adalah untuk menurunkan Intersymbol Interference (ISI) menjadi nol dalam permasalahan bebas noise. ZF akan membalikan efek kanal dengan cara mengalikan vektor sinyal yang diterima dengan pseudo-inverse dari matrik kanal. Untuk menghilangkan interferensi, detektor linier ZF harus memenuhi kondisi berikut [2]:

\section{$W_{2 \pi} H=1$}

dimana bentuk dari demodulator linier ZF adalah sebagai berikut:

$$
W_{2 \pi}=\left(H^{H} H\right)^{-1} H^{H}
$$

Dengan:

$\mathrm{H}=$ Matriks kanal

$\mathrm{I}=$ Matriks identitas

$(.)^{\mathrm{H}}=$ Transpose Hermitian

Matriks ini dikenal dengan nama pseudo-inverse untuk matriks $\mathrm{m} x \mathrm{n}$. Penerima dapat memperoleh perkiraan sinyal dengan ZF equalization, seperti berikut:

\section{f $-W_{2 f} \gamma$}

dimana $\hat{X}$ adalah matriks perkiraan dari sinyal transmisi yang diterima oleh penerima dan $\mathrm{Y}$ adalah simbol dari antena pengirim.

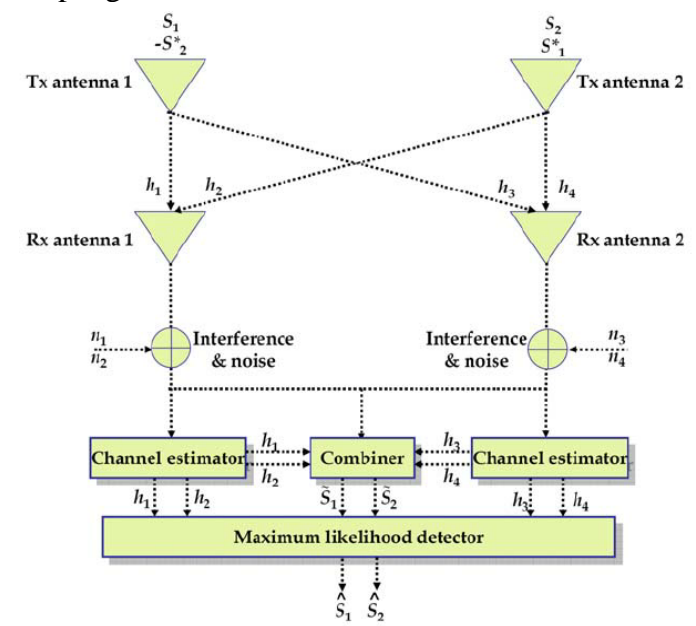

Gambar 4. Skema MIMO Alamouti 2 × 2

\section{Successive Interference Cancellation}

Kita dapat mendapatkan keuntungan tambahan dengan menggunakan teknik pembatalan gangguan atau yang sering disebut Interference Cancellation setelah melakukan ekualisasi linier [2]. SIC adalah sebuah detektor yang mendeteksi user secara bersamaan. SIC beroperasi secara sederhana mengurangi pertambahan dari MAI dengan pengurangan kekuatan sinyal dari pengguna. Cara kerja dari SIC yaitu membatalkan sinyal terkuat terlebih dahulu atau yang paling dianggap mengganggu lalu diikuti oleh sinyal terkuat selanjutnya sampai semua sinyal hilang. SIC awalnya memberi peringkat dahulu terhadap kekuatan dari sinyal tersebut sebelum dibatalkan, yang diperoleh dengan estimasi kanal terpisah atau langsung dari detektor konvensional.

Setelah proses decoding, daya yang diterima pada penerima yang terhubung dengan sinyal transmisi $x_{1}$ dan $x_{2}$ adalah: 


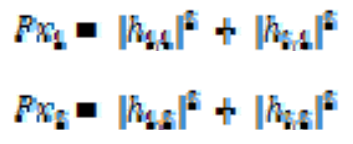

Jika $P_{X_{1}}>P_{X_{2}}$, maka penerima memutuskan untuk menghilangkan efek $\hat{x}_{1}$ dari sinyal vektor Y. Kemudian $\hat{x}_{2}$ diperkirakan kembali sebagai:

\section{$\eta=h x_{g}+n$}

Dimana $r$ adalah sinyal vektor yang telah diperkirakan ulang. Kita juga memperkirakan sinyal transmisi $x_{2}$ dengan menggabungkan informasi dari beberapa salinan sinyal yang diterima. Maka, hasil akhir untuk $x_{2}$ dapat dinyatakan sebagai berikut:

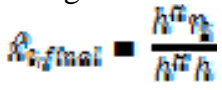

Dengan cara yang sama, jika $P_{x_{1}}<F_{x_{\mathrm{g}}}$ maka penerima memutuskan untuk menghilangkan efek $\hat{x}_{2}$ dari sinyal vektor Y. Kemudian $f_{\perp}$ dapat diperkirakan kembali seperti langkah diatas.

\section{DESAIN DAN IMPLEMENTASI SISTEM}

Pada bab ini dijelaskan tentang pemodelan sistem komunikasi pengirim dan penerima yang akan digunakan. Pemodelan sistem tersebut dapat dilihat pada gambar 5 . Pada bagian ini adalah bagian awal dari perancangan suatu sistem. Untuk membangun sebuah sistem diperlukan parameter simulasi yang ingin digunakan. Untuk parameter simulasi yang dibunakan dapat dilihat pada tabel 2 .

Pada gambar 5 dapat dijelaskan rancangan sistem kerja dari simulasi adalah sebagai berikut:

1. Penentuan jumlah dan letak sensor yang digunakan, yaitu sensor detak jantung/ elektrokardiogram (ECG) yang diletakkan di dada dan sensor aktivitas otak/ elektroensefalogram(EEG) yang diletakkan di kepala.

2. Pembangkitan dari data sensor yang dimodelkan sebagai bilangan biner acak sebagai data masukan sebanyak 20000 bit data.

3. Bit informasi tersebut dimodulasi menggunakan teknik modulasi BPSK

4. Proses spreading menggunakan perkalian XOR antara data informasi dengan PN code yang digunakan yaitu memakai kode gold 31.

5. Proses pengiriman bit informasi dengan menggunakan MIMO alamouti. Bit tersebut sebelum dipancarkan, sinyal dikodekan terlebih dahulu dengan mengirimkan 2 simbol $\left(s_{0}\right.$ dan $\left.s_{1}\right)$ yang berbeda dalam satu waktu. Pada waktu pertama (t) antena ke-1 mengirimkan sinyal berupa simbol $s_{0}$ dan antena ke-2 mengirimkan sinyal berupa simbol $s_{\mathfrak{q}}$. Kemudian pada waktu kedua

$(\mathrm{t}+\mathrm{T})$ simbol dari masing masing antena pemancar tersebut dikonjuget sehingga menjadi simbol $-s_{1}^{*}$ pada antena ke-1 dan simbol $s_{0}^{*}$ pada antena ke-2.

6. Simbol dipancarkan oleh antena pemancar melalui kanal yang terdapat gangguan noise dan multipath fading sehingga simbol yang dipancarkan akan mengalami gangguan.

7. Simbol data tersebut akan diterima oleh antena penerima MIMO decoder.
8. Sinyal yang diterima tersebut akan diproses dengan despreading dengan melakukan perkalian dengan PN code yang sama seperti PN code pada sisi pengirim. Hasil perkalian tersebut akan diperoleh urutan sinyal informasi dalam bentuk bit.

9. Bit informasi tersebut akan di demodulasi secara linier menggunakan equalizer Zero Forcing (ZF) dengan cara mengalikan kanal dengan pseudoinversenya.

10. Melakukan metode Successive Interference Cancellation untuk mengurangi MAI.

11. Proses demodulasi BPSK pada penerima dilakukan untuk memperoleh kembali bit bit informasi yang sebelumnya telah dimodulasi pada sisi pemancar.

12. Penentuan informasi bit yang diterima

13. Pendeteksian tingkat kesalahan selama proses pengiriman dengan melihat Bit Error Rate (BER) yang timbul.

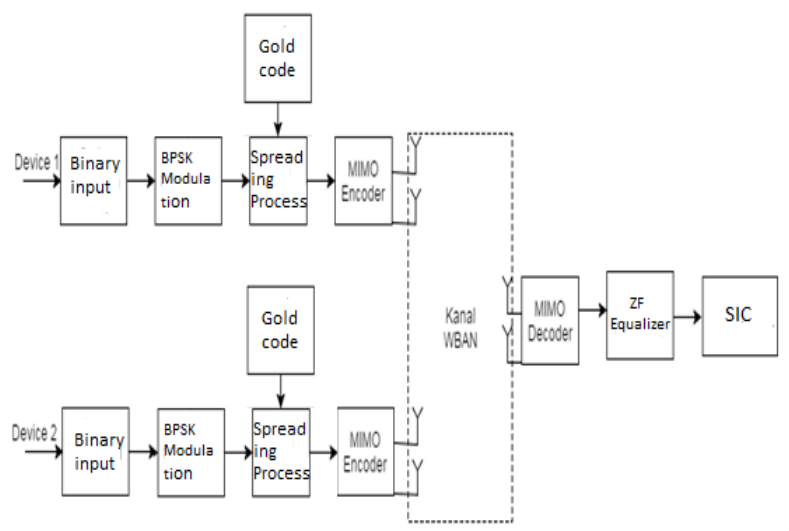

Gambar 5. Diagram Blok Sistem Komunikasi

\begin{tabular}{|c|c|}
\hline Parameter & Nilai \\
\hline Jumlah data & 20.000 \\
\hline Modulasi & BPSK \\
\hline Skema MIMO & STBC Alamouti 2 X 2 \\
\hline Spreading Code & Gold Code \\
\hline Jumlah Register & 5 \\
\hline Panjang Kode & 31 bit \\
\hline Preferred Pairs & {$[5,3]=\left[\begin{array}{llllll}1 & 1 & 1 & 1 & 1\end{array}\right]$} \\
\hline & {$[5,4,3,2]=\left[\begin{array}{lllll}1 & 1 & 1 & 1 & 1\end{array}\right]$} \\
\hline Model Kanal & Rayleigh, WBAN CM4 \\
\hline Letak Sensor & $0^{\circ}$ \\
\hline Equalizer & $\mathrm{ZF}$ \\
\hline Skema Interference Cancellation & SIC \\
\hline
\end{tabular}

Maka hasil dari sinyal yang ditransmisikan dari antena pengirim dapat di ekspresikan sebagai berikut:

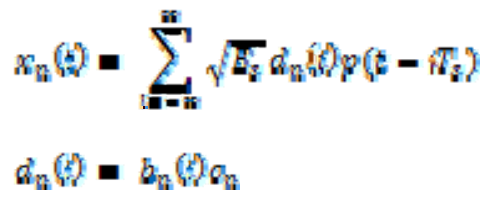

Dimana

$\boldsymbol{d}_{n}(6)$ : Simbol informasi

$b_{12}(0)$ : Urutan data

$c_{n} \quad$ : Kode spreading gold

$E_{z} \quad$ : Energi pulsa

$\boldsymbol{v}(\mathbf{l})$ : Respon impuls

Untuk impuls respon kanal pada kanal WBAN dengan propagasi Multipath dapat diekspresikan sebagai berikut: 


$$
h(b)=\sum_{n}^{6} x(b) d\left(t-\pi_{p}\right)
$$

Dimana:

a. : Koefisien fading dari jalur, dimana besarannya mengikuti distribusi log normal

gíne : : Fungsi delta Dirac

$T_{p} \quad$ : Resolusi minimum multipath

Pada sisi penerima, sinyal yang diterima dapat diekspresikan sebagai berikut:

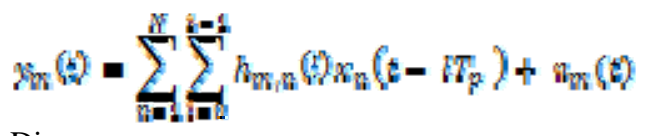

Dimana:

$h_{w_{i}}\left(b^{n}\right)$ : Koefisien Fading dari jalur untuk sinyal dari antena transmitter ke antena receiver

$n_{\mathrm{N}}\left(t^{n}\right)$ : Additive White Gaussian Noise (AWGN)

\section{PENGUJIAN DAN ANALISIS}

\section{A. Analisis Sistem Komunikasi SISO}

Pengujian pertama adalah melakukan pengamatan kinerja sistem saat menggunakan satu input dan satu output. Secara teori pada pengiriman dengan SISO akan memperbesar jumlah eror pada data. Hal ini dapat dibuktikan pada hasil simulasi yang telah dilakukan. Untuk lebih jelasnya dapat dilihat pada hasil kurva SISO yang terdapat pada gambar 6 .

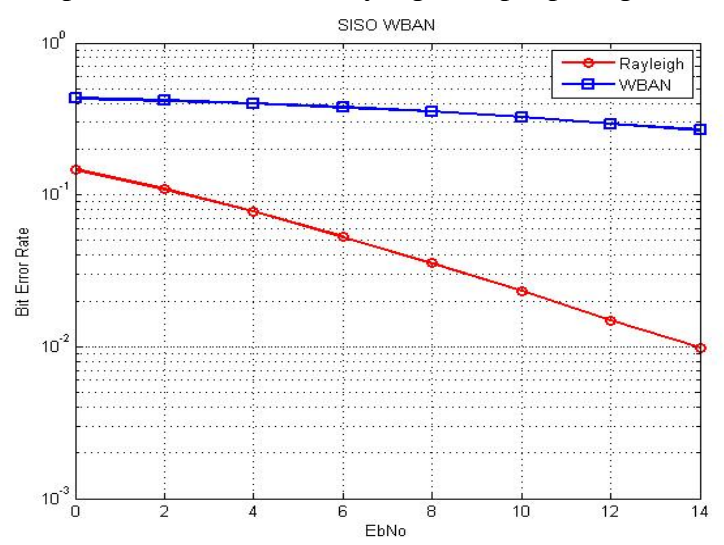

Gambar 6. Kinerja sistem pada pengiriman SISO WBAN

Pada sistem ini didapatkan nilai BER yang sangat besar. Pada saat nilai EbNo sebesar $0 \mathrm{~dB}$ didapatkan BER sebesar 0,4324. Lalu pada saat nilai EbNo sebesar $14 \mathrm{~dB}$ didapatkan BER sebesar 0,2672. Nilai tersebut sangatlah besar dan tidak ada perbedaan yang siknifikan pada setiap EbNo. Artinya pada pengiriman SISO pada kanal WBAN tidak bisa dilakukan karena sangat rentan terhadap gangguan sehingga eror yang didapatkan sangat besar.

\section{B. Analisis Sistem MIMO}

Pada simulasi ini dilakukan pengamatan kinerja sistem saat menggunakan dua antena input dan dua antena output atau yang disebut MIMO 2 x 2 pada kanal WBAN. Teknik MIMO yang digunakan yaitu dengan STBC Alamouti. Secara teori yang ada teknik MIMO STBC Alamouti dapat membuat tingkat eror semakin kecil karena memang fungsinya adalah untuk meningkatkan reliabilitas. Dengan menggunakan skema MIMO Alamouti diharapkan dapat meningkatkan reliabilitas pada kanal WBAN. Untuk lebih jelasnya dapat dilihat pada hasil kurva MIMO ZF yang terdapat pada gambar 7 .

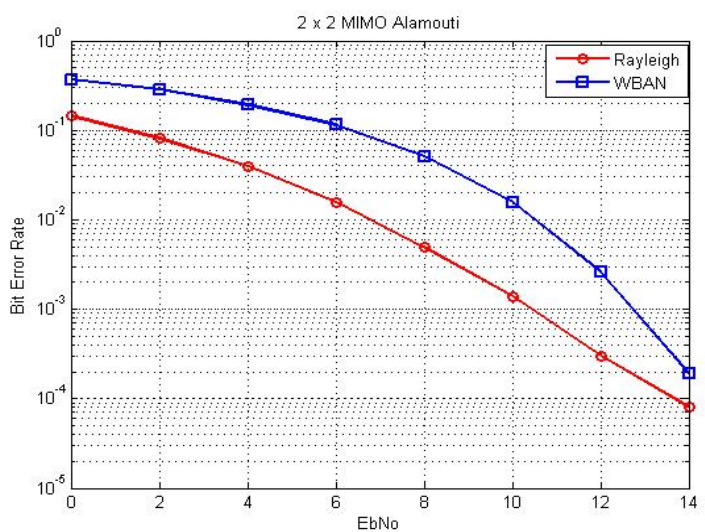

Gambar 7. Kinerja sistem pada pengiriman MIMO WBAN

Pada saat nilai EbNo $=0 \mathrm{~dB}$ nilai BER dari kedua sistem tersebut tidak berbeda jauh yaitu 0,4324 untuk SISO dan 0,3120 pada MIMO. Nilai BER pada sistem MIMO pada kanal WBAN jauh lebih baik dibandingkan dengan sistem SISO. Nilai BER pada kedua sistem tersebut linier. Semakin besar nilai EbNo maka nilai dari BER akan semakin kecil. Pada nilai EbNo= $14 \mathrm{~dB}$ didapatkan perbedaan yang cukup signifikan dari kedua sistem tersebut yaitu sebesar 0,2672 pada SISO dan 0,00057 pada MIMO. Maka didapatkan hasil BER pada MIMO turun sebesar $10^{-3}$ dibandingkan dengan pada sistem SISO.

\section{Analisis Sistem Menggunakan Equalizer}

Selanjutkan disimulasikan sistem MIMO menggunakan equalizer. Teknik ekualisasi yang digunakan adalah dengan Zero Forcing (ZF). Berdasarkan teori ZF dapat menghilang kan intersimbol interference (ISI) sehingga hasilnya akan didapatkan nilai BER yang lebih kecil dibandingkan dengan tanpa ekualisasi. Hal itu dapat dibuktikan data yang didapatkan dari simulasi. Untuk lebih jelasnya dapat dilihat pada hasil kurva MIMO ZF yang terdapat pada gambar 8.

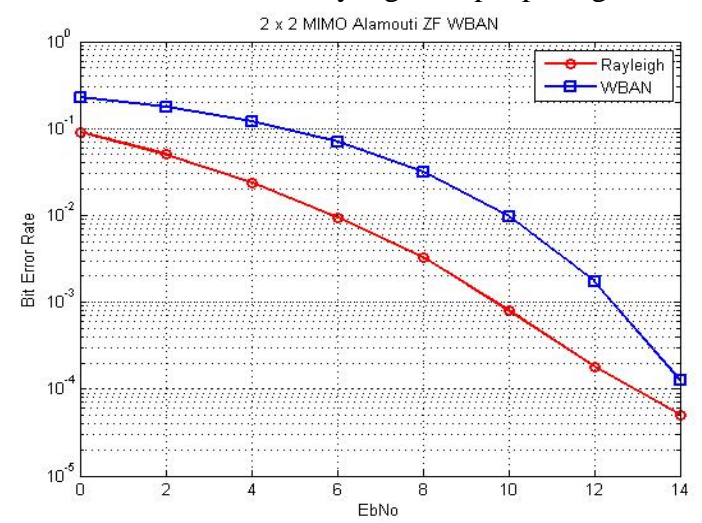

Gambar 8. Kinerja sistem pada pengiriman MIMO ZF WBAN

Berdasarkan kurva hasil simulasi didapatkan nilai BER MIMO ZF lebih kecil dibandingkan MIMO tanpa ekualisasi. Pada $E b N o=0 \mathrm{~dB}$ didapatkan nilai BER sebesar 0,2319. Nilai ini turun sebesar 0,0701 dibandingkan dengan MIMO tanpa ekualisasi. Lalu pada EbNo= $14 \mathrm{~dB}$ didapatkan nilai BER sebesar 0,0001375. Nilai ini lebih kecil 0,0004325 
dibandingkan dengan MIMO tanpa ekualisasi. Hal ini dapat membuktikan bahwa kinerja dengan menambahkan equalizer pada sistem komunikasi dapat meningkatkan kualitas sistem tersebut.

\section{Analisis Sistem dengan Interference Cancellation}

Selanjutkan disimulasikan sistem MIMO menggunakan Zero Forcing dan Interference Cancellation. Skema Interference Cancellation yang digunakan adalah dengan Successive Interference Cancellation. Berdasarkan teori SIC digunakan untuk menghilangkan Multipath Access Interference (MAI), sehingga hasilnya akan didapatkan nilai BER yang lebih kecil lagi dibandingkan tanpa menerapkan metode Interference Cancellation. Hal itu dapat dibuktikan dengan data hasil simulasi. Untuk lebih jelasnya dapat dilihat pada hasil kurva MIMO ZF SIC yang terdapat pada gambar 9 .

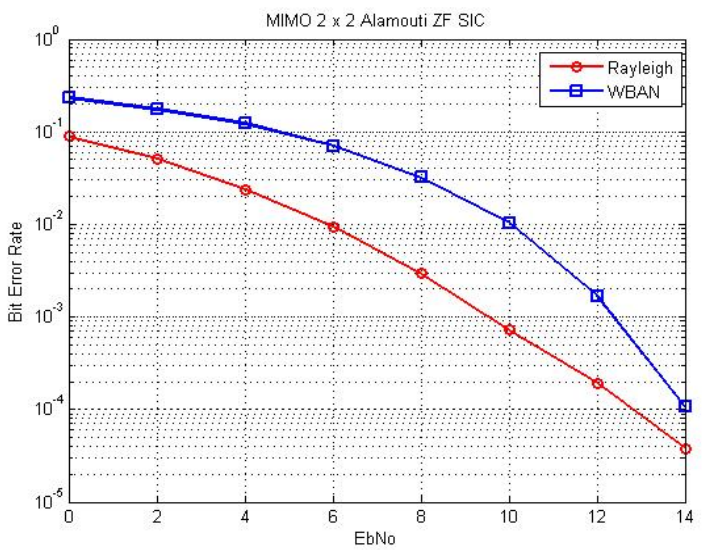

Gambar 9. Kinerja sistem pada pengiriman MIMO ZF SIC WBAN

Dapat dilihat penurunan BER sangat kecil jika dibandingkan dengan tanpa metode Interference Cancellation. Misalnya pada saat $\mathrm{EbNo}=2 \mathrm{~dB}$ didapatkan nilai BER sebesar 0,1756 pada MIMO ZF dan 0,1664 pada MIMO ZF SIC. Dapat dilihat pula nilai BER pada MIMO ZF SIC lebih besar dibandingkan dengan MIMO ZF yaitu pada saat $E b N o=12 \mathrm{~dB}$. Pada saat EbNo $=14 \mathrm{~dB}$ didapatkan nilai BER yang sangat kecil untuk MIMO ZF SIC yaitu 0,0001. Namun dari penerapan semua metode didapatkan hasil yang menimbulkan eror paling kecil adalah dengan penerapan MIMO ZF dan dengan menggunakan metode SIC.

\section{KESIMPULAN}

1. Kinerja sistem komunikasi MIMO pada kanal WBAN lebih renda dibandingkan dengan kanal Rayleigh dengan perbedaan BER sebesar 0,00561 pada $\mathrm{EbNo}=14$.

2. MIMO Alamouti dapat meningkatkan reliabilitas dari sebuah sistem komunikasi jika dibandingkan dengan sistem SISO dengan nilai BER turun sebesar 0,2615 pada EbNo=14.

3. Menambahkan equalizer pada sistem komunikasi dapat mengurangi ISI yang ditandai dengan pengurangan nilai BER sebesar 0,00556 pada $\mathrm{EbNo}=14$.

4. Menggunakan equalizer dan penambahan skema Successive Interference Cancellation dapat mengurangi nilai eror jika dibandingkan dengan sistem komunikasi hanya menggunakan equalizer didapatkan pengurangan nilai BER sebesar 0,0000375 pada $\mathrm{EbNo}=14$.

5. Skema Interference Cancellation yang efisien adalah dengan mengimplementasikan MIMO Alamouti dengan ekualisasi Zero Forcing dan Successive Interference Cancellation dihasilkan BER sebesar 0,0001 pada saat $\mathrm{EbNo}=14$.

\section{DAFTAR PUSTAKA}

[1] Gupta, Sandeep, “Body Area Networks Safety, Security, Sustainability”, Cambridge, 2013, pp. $9-24$.

[2] Bae J.N, Choi H.Y., Kim J.Y., "Efficient Interference Cancellation Scheme for Wireless Body Area Network”, Journal of Commnunication and Networks vol 13 No.2, 2011.

[3] “Channel Model for Body Area Network”, IEEE P802.15

[4] Meel J., “Spread Spectrum”, De Nayer Instituut, 2009, pp. 12 - 18.

[5] Setiawan, Afri Dani, "Implementasi dan Evaluasi Kinerja Kode Gold pada CDMA Menggunakan WARP ”, Jurusan Teknik Elektro ITS, 2015.

[6] Parveen, Nazia, "Multipath Interference Cancellation in MIMO Mobile Cellular System”, International Journal of Distributed and Parallel Systems vol 3 No.3, 2012.

[7] B. Ezio, C. Robert, C. Anthony, G. Andrea, P. Arogyaswami, "MIMO Wireless Communications", Cambridge, 2007, Ch. 3.

[8] Mandeep, K. Deepak, "Performance Analysis of Space Time Block Code Over Rayleigh Fading Channel”, International Journal of Engineering Research \& Technology vol 2 No.8, 2013. 